\title{
Virulent non-capsulate Yersinia pestis variants constructed by insertion mutagenesis
}

\author{
I. G. DROZDOV, A. P. ANISIMOV†, S. V. SAMOILOVA, I. N. YEZHOV, S. A. YEREMIN, \\ A. V. KARLYSHEV*, V. M. KRASILNIKOVA* and V. I. KRAVCHENKO*
}

Department of Genetics, Russian Anti-Plague Research Institute "Microbe", Universitetskaya Street 46, 410071 Saratov and "Department of Genetics, State Research Institute of Applied Microbiology, Obolensk, 142279 Moscow Region, Russia

\begin{abstract}
Summary. Insertion mutagenesis with the help of the plasmid pFS23 was used to generate Yersinia pestis fra mutants. The results of $\mathrm{pFra}^{-}$strain production under non-selective conditions suggested that such $Y$. pestis variants may be generated in natural plague foci at high frequency and may participate in supporting the epizootic process. Present data suggest that the reduction of virulence in $\mathrm{Fra}^{-}$strains reported by the majority of investigators was connected with the use of $Y$. pestis variants carrying additional unidentified mutations. It was shown that the loss of the ability to produce capsular antigen (FI) alone or in combination with absence of murine toxin production did not lead to an increase in LD50 absolute values. Simultaneous loss of these two virulence determinants did not influence the duration of survival of the infected animals. However, absence of only FI antigen production in the infecting strain resulted in prolonged survival of the infected animals. Conversion of plague infection from acute to chronic form is probably dependent on the animal host species and the $Y$. pestis parent strain subjected to mutagenesis.
\end{abstract}

\section{Introduction}

It has been suggested that the ability of noncapsulate Yersinia pestis variants to cause chronic infection $^{1}$ can play an important role in supporting the epizootic process in natural plague foci. ${ }^{2}$ The laboratory-constructed non-capsulate strains usually showed reduced virulence. ${ }^{3}$ The known methods of construction of non-capsulate $Y$. pestis strains were based on spontaneous or induced mutant selections that were of low productivity ${ }^{4}$ or led to many unforeseen mutations. ${ }^{5}$ Thus, the incubation of $Y$. pestis cultures on magnesium-oxalate agar at $37^{\circ} \mathrm{C}$ led not only to fra locus deletions of the plasmid $\mathrm{pFra}^{5}$ but also to insertions or deletions of the plasmid pCad and to $Y$. pestis chromosomal mutations. ${ }^{6}$ However, the treatment of $Y$. pestis cells by ethidium bromide failed to achieve directed mutagenic action. ${ }^{7}$ These mutations resulted in uncontrolled changes of the biological properties of the fra mutants.

Recently the plasmid-located fra operon encoding capsular antigen (fraction I; FI) was cloned and sequenced. $^{8-12}$ It was shown that the fra operon

Received 24 Feb. 1994; revised version accepted 12 Oct. 1994. †Correspondence should be sent to Dr A. P. Anisimov. consists of four ${ }^{11}$ or five ${ }^{8}$ open reading frames able to encode proteins. The FI structural gene ycaF (cafl) was localised near the $C l a \mathrm{I}$ site. ${ }^{8,10}$

The objective of the present study was to construct $y c a F$ (cafl) mutants and $\mathrm{pFra}^{-}$variants of virulent $Y$. pestis strains with the help of insertion mutagenesis and to study their biological properties.

\section{Materials and methods}

\section{Bacterial strains}

$Y$. pestis strains used in the study are listed in the table. ${ }^{13}$ Escherichia coli strain $\mathrm{HB} 101^{14}$ was used for genetic engineering manipulations.

\section{Media and culture conditions}

The cultures were grown on Luria Broth medium (LB; tryptone $10 \mathrm{~g}$, yeast extract $5 \mathrm{~g}, \mathrm{NaCl} 10 \mathrm{~g}$ ) supplemented with agar $2 \%, \mathrm{pH} 7 \cdot 2$, at $37^{\circ} \mathrm{C}($ E. coli; $Y$. pestis for $\mathrm{FI}$ immunochemical testing) and at $28^{\circ} \mathrm{C}$ ( $Y$. pestis in all the other cases). Antibiotics were used in the following concentrations: kanamycin $50 \mathrm{mg} / \mathrm{L}$ and ampicillin $100 \mathrm{mg} / \mathrm{L}$. 
Table. Y.pestis strains: relevant attributes

\begin{tabular}{|c|c|c|}
\hline Strain no. & $\begin{array}{l}\text { Virulence determinants } \\
\text { (Phenotype) }\end{array}$ & $\begin{array}{l}\text { Source or } \\
\text { reference }\end{array}$ \\
\hline $231(708)$ & $\mathrm{Fra}^{+} \mathrm{Tox}^{+} \mathrm{Lcr}^{+} \mathrm{V}^{+} \mathrm{Pst}^{+} \mathrm{Fb}^{+} \mathrm{Cg}^{+} \mathrm{Pgm}^{+*}$ & $\mathrm{CCIM} \dagger$ \\
\hline $231 \mathrm{pFra} / \mathrm{pFS} 23$ & $\mathrm{Fra}^{-} \mathrm{Tox}^{+} \mathrm{Lrr}^{+} \mathrm{V}^{+} \mathrm{Pst}^{+} \mathrm{Fb}^{+} \mathrm{Cg}^{+} \mathrm{Pgm}^{+}$ & This study \\
\hline $231 \mathrm{pFra}^{-}$ & $\mathrm{Fra}^{-} \mathrm{Tox}^{-} \mathrm{Lcr}^{+} \mathrm{V}^{+} \mathrm{Pst}^{+} \mathrm{Fb}^{+} \mathrm{Cg}^{+} \mathrm{Pgm}^{+}$ & This study \\
\hline $231 \mathrm{pPst}^{-}$ & $\mathrm{Fra}^{+} \mathrm{Tox}^{+} \mathrm{Lcr}^{+} \mathrm{V}^{+} \mathrm{Pst}^{-} \mathrm{Fb}^{-} \mathrm{Cg}^{-} \mathrm{Pgm}^{+}$ & $\begin{array}{l}\text { The author's } \\
\text { collection }\end{array}$ \\
\hline $231 \mathrm{pPst}^{-} \mathrm{pFra} / \mathrm{pFS} 23$ & $\mathrm{Fra}^{-} \mathrm{Tox}^{+} \mathrm{Lcr}^{+} \mathrm{V}^{+} \mathrm{Pst}^{-} \mathrm{Fb}^{-} \mathrm{Cg}^{-} \mathrm{Pgm}^{+}$ & This study \\
\hline $231 \mathrm{Psb}^{-}$pFra/pFS23 & $\mathrm{Fra}^{-} \mathrm{Tox}^{+} \mathrm{Lcr}^{+} \mathrm{V}^{+} \mathrm{Pst}^{+} \mathrm{Fb}^{+} \mathrm{Cg}^{+} \mathrm{Pgm}^{-}$ & This study \\
\hline 358 & $\mathrm{Fra}^{+} \mathrm{Tox}^{+} \mathrm{Lcr}^{+} \mathrm{V}^{+} \mathrm{Pst}^{+} \mathrm{Fb}^{+} \mathrm{Cg}^{+} \mathrm{Pgm}^{+}$ & CCIM \\
\hline $358 \mathrm{pFra} / \mathrm{pFS} 23$ & $\mathrm{Fra}^{-} \mathrm{Tox}^{+} \mathrm{Lcr}^{+} \mathrm{V}^{+} \mathrm{Pst}^{+} \mathrm{Fb}^{+} \mathrm{Cg}^{+} \mathrm{Pgm}^{+}$ & This study \\
\hline $358 \mathrm{pFra}^{-}$ & $\mathrm{Fra}^{-} \mathrm{Tox}^{-} \mathrm{Lcr}^{+} \mathrm{V}^{+} \mathrm{Pst}^{+} \mathrm{Fb}^{+} \mathrm{Cg}^{+} \mathrm{Pgm}^{+}$ & This study \\
\hline $358 \mathrm{pPst}^{-}$ & $\mathrm{Fra}^{+} \mathrm{Tox}^{+} \mathrm{Lcr}^{+} \mathrm{V}^{+} \mathrm{Pst}^{-} \mathrm{Fb}^{-} \mathrm{Cg}^{-} \mathrm{Pgm}^{+}$ & $\begin{array}{l}\text { The author's } \\
\text { collection }\end{array}$ \\
\hline $358 \mathrm{pPst}^{-} \mathrm{pFra} / \mathrm{pFS} 23$ & $\mathrm{Fra}^{-} \mathrm{Tox}^{+} \mathrm{Lcr}^{+} \mathrm{V}^{+} \mathrm{Pst}^{-} \mathrm{Fb}^{-} \mathrm{Cg}^{-} \mathrm{Pgm}^{+}$ & This study \\
\hline
\end{tabular}

*Fra, synthesis of capsular antigen; Tox, synthesis of mouse exotoxin; Lcr, low calcium response; $\mathrm{V}$, synthesis of $\mathrm{V}$ antigen; Pst, synthesis of pesticin; $\mathrm{Fb}$, fibrinolysin activity; $\mathrm{Cg}$, coagulase activity; Pgm, storage of exogenous haemin.

†CCIM, The Culture Collection of Institute "Microbe".

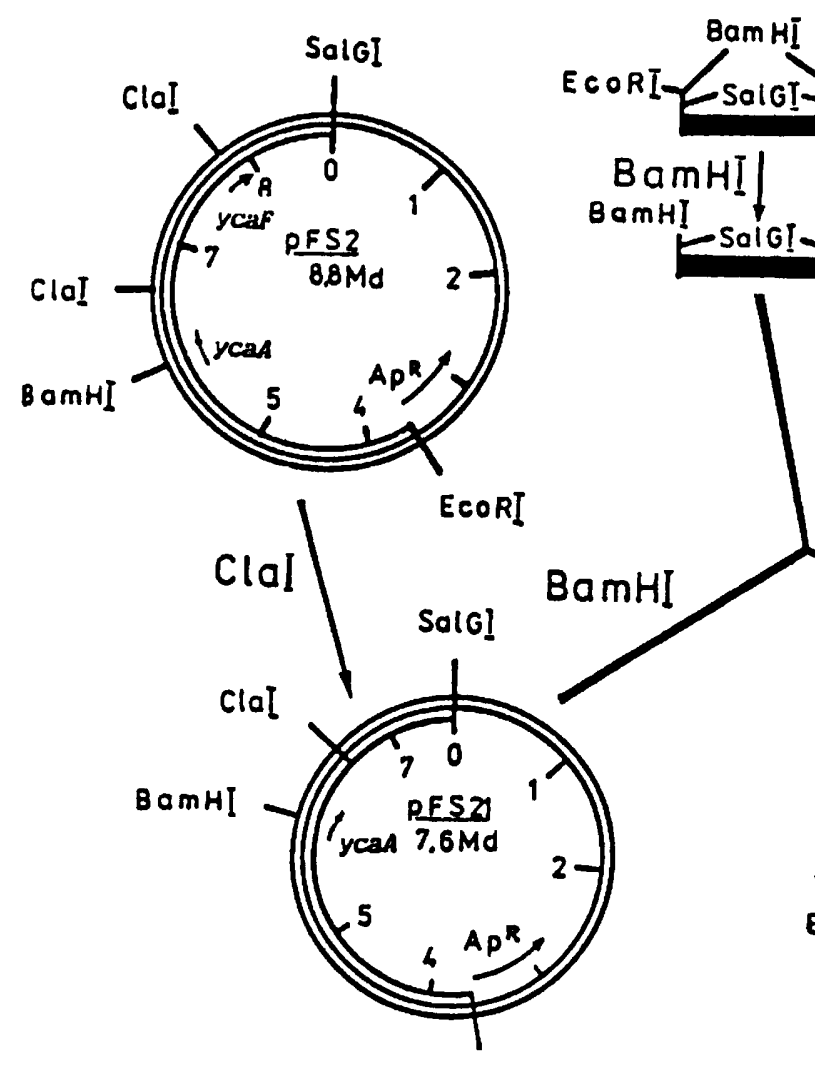

ECORI

Fig. 1. Construction of pFS23. Isolation of plasmid DNA by alkali-lysis method and genetic engineering methods was performed essentially as described by Maniatis et al. ${ }^{14}$ Plasmid pFS21 was constructed by deletion of the ClaI-ClaI fragment from previously constructed plasmid pFS2. ${ }^{10}$ The BamHI-BamHI fragment with $k a n\left(\mathrm{Km}^{\mathrm{R}}\right)$ locus from pUC4K ${ }^{16}$ was isolated and cloned into BamHI site of pFS21. The plasmid generated was named pFS23. The vector fragment of the plasmid pFS23 carried the bla $\left(\mathrm{Ap}^{\mathrm{R}}\right)$ gene and the replication region of the plasmid ColEl. This ColEl ori could not provide stable preservation of recombinant plasmids constructed on its basis in $Y$. pestis recipient cells under the non-selective conditions. ${ }^{17}$

\section{Main phenotypic determinants}

The main phenotypic determinants encoded by $Y$. pestis plasmids and chromosome were analysed as described previously ${ }^{15}$ (FI antigen production was tested by haemagglutination tests for FI antigen detection).

\section{Construction of the pFS23 plasmid}

The scheme of the pFS23 plasmid construction is shown in fig. 1. Plasmids were isolated from $E$. coli and $Y$. pestis by the alkali-lysis method of Birnboim and Doly. ${ }^{14}$ Protocols for restriction enzyme digestions, and the use of T4 DNA ligase, were essentially as 
described by Maniatis et al. ${ }^{14}$ All enzymes were used as recommended by the manufacturers.

Plasmid pFS21 was constructed from previously constructed plasmid $\mathrm{pFS} 2^{10}$ by deleting the 1986-bp ClaI-ClaI fragment and ligating the two ends. This deletion includes the 173-bp region from the beginning of the FI structural gene ycaF. The BamHI-BamHI fragment with $k a n\left(\mathrm{Km}^{\mathrm{R}}\right)$ locus from $\mathrm{pUC} 4 \mathrm{~K}^{16}$ was isolated and cloned into the BamHI site of pFS21. The plasmid generated was named pFS23. The vector fragment of the plasmid pFS23 carried the bla $\left(\mathrm{Ap}^{\mathrm{R}}\right)$ gene and the replication region of the plasmid ColE1. This ColE1 ori could not provide stable preservation of recombinant plasmids constructed on its basis in $Y$. pestis recipient cells in unselective conditions. ${ }^{17}$

\section{Transformation of $Y$. pestis}

$Y$. pestis was transformed with plasmid DNA by electroporation as described by Yezhov et al. ${ }^{18}$

\section{Construction of the ycaF $Y$. pestis mutants}

Recipient $Y$. pestis cells were transformed by the specially constructed target plasmid pFS23. The plasmid pFra SalGI-EcoRI fragment cloned in pFS23 had a deletion of the ClaI-ClaI region consisting of a part of $y c a F$ gene and insertion of kan gene into the BamHI site of fra operon. The $\mathrm{Km}^{\mathrm{R}}$ marker flanked by the regions homologous to the pFra fra operon was able to enter into homologous recombination with the latter. This allowed generation of homologous recombinants with the intact DNA sequence substituted by a $y c a F$-defective DNA fragment of the plasmid pFS23 harbouring the $\mathrm{Km}^{\mathrm{R}}$ marker. Cultivation of recombinant cells on ampicillin-free medium did not prevent elimination of the $\mathrm{pFS} 23$ vector region and allowed selection of $Y$. pestis $\mathrm{Km}^{\mathrm{R}} \mathrm{Ap}^{\mathrm{S}} \mathrm{Fra}^{-} \mathrm{Tox}^{+}$variants. The advantages of this method were the absence of translocations and the stability of the recombinants.

Selection was performed in the following way. $\mathrm{Km}^{\mathrm{R}}$ clones of the $Y$. pestis transformants were examined for expression of the $\mathrm{Ap}^{\mathrm{R}}$ phenotype. $\mathrm{Km}^{\mathrm{R}} \mathrm{Ap}^{\mathrm{S}}$ variants were found at a frequency of $0 \cdot 1-15 \%$ of the whole recombinant cell population.

Preliminary passage of the $\mathrm{Km}^{\mathrm{R}}$ transformant mixture in previously immunised mice $\left(10^{8} \mathrm{cfu} /\right.$ animal) increased the proportion of the tested $\mathrm{Km}^{\mathrm{R}} \mathrm{Ap} \mathrm{p}^{\mathrm{S}}$ clones in the $Y$. pestis cultures from dead animals up to $50-100 \%$. These mice were immunised by FI antigen $(20 \mu \mathrm{g} /$ animal $) 21$ days before injection. The $\mathrm{Km}^{\mathrm{R}} \mathrm{Ap}^{\mathrm{s}}$ clones were tested for $\mathrm{FI}$ antigen production by haemagglutination. $\mathrm{Km}^{\mathrm{R}} \mathrm{Ap}^{\mathrm{s}} Y$. pestis cultures were shown to be $\mathrm{Fra}^{-}$in all clones analysed.

\section{Selection of $p F r a^{-}\left(p F r a / p F S 23^{-}\right)$clones}

The main difficulty in the construction of $Y$. pestis $\mathrm{pFra}^{-}$variant is the absence of a convenient marker for negative selection. In the selective method de- scribed below, the use of $Y$. pestis strains carrying $\mathrm{pFra} / \mathrm{pFS} 23$ plasmids with the $\mathrm{Km}^{\mathrm{R}}$ marker provided a solution to this problem.

The $Y$. pestis $231 \mathrm{pFra} / \mathrm{pFS} 23$ and $358 \mathrm{pFra} / \mathrm{pFS} 23$ cultures were grown on LB agar plates containing kanamycin at subinhibitory concentrations. These concentrations were defined experimentally for every strain. About 300 cells were sown on agar plates containing kanamycin $(1-10 \mu \mathrm{g} / \mathrm{ml})$ and grown at $28^{\circ} \mathrm{C}$. The loss of $\mathrm{Km}^{\mathrm{R}}$ was manifest by inhibition of cell growth. Two variants of bacterial colonies were seen on the plates containing kanamycin $(1-2 \mu \mathrm{g} / \mathrm{ml})$ after incubation for 3-5 days; these were $0.5-1.5 \mathrm{~mm}$ and $2 \cdot 0-3.5 \mathrm{~mm}$ in diameter respectively. The clones from the first group were analysed on agar plates containing a completely inhibitory concentration of kanamycin $(50 \mu \mathrm{g} / \mathrm{ml}) . \mathrm{Km}^{\mathrm{s}}$ mutations of these strains arose at the frequency of $\left(2.5 \times 10^{-5}-5.0 \times 10^{-5}\right) . \mathrm{Km}^{\mathrm{s}}$ clones examined by plasmid screening ${ }^{14}$ were shown to be $\mathrm{pFra}^{-}$in all clones analysed.

\section{Definition of bacterial virulence for mice and guinea- pigs}

Outbred mice weighing $c .20 \mathrm{~g}$ or outbred guineapigs weighing $c .250 \mathrm{~g}$ were given suspensions of 48 -h agar cultures in $\mathrm{NaCl} 0.89 \%$ solution in a total volume of $0.2 \mathrm{ml}$ (with 10 -fold dilutions) by subcutaneous injection. The animals were observed for 21 days. LD50 values and confidence intervals were measured according to the method of Kärber modified by Ashmarin and Vorob'ov. ${ }^{19}$ The confidence interval was determined for a probability of $95 \%$.

\section{Results}

\section{Comparative analyses of $\mathrm{Y}$. pestis $\mathrm{Fra}^{+}$and $\mathrm{Fra}^{-}$ strains}

The main biological properties of the strains were compared. There were no differences between wild strains and their $\mathrm{Fra}^{-}$variants in: (i) cultural properties; (ii) nutritional requirements; (iii) fermentation of glycerol, rhamnose and urea; (iv) phage sensitivity. The parent strains and their $\mathrm{Fra}^{-}$derivatives did not differ in other virulence-related properties such as low calcium response, synthesis of V-antigen, synthesis of pesticin, fibrinolysin activity, coagulase activity or storage of exogenous haemin. Synthesis of murine exotoxin was retained by the $\mathrm{Fra}^{-}$strains generated with the help of the insertion mutagenesis but not in the $\mathrm{pFra}^{-}$variants.

No consistent differences were found in the LD50 values for mice and guinea-pigs of parent $\mathrm{Fra}^{+}$strains and their $\mathrm{Fra}^{-}$derivatives. The only exception was a pair of strains, 231 $\mathrm{Psb}^{-}$and 231 $\mathrm{Psb}^{-} \mathrm{pFra} / \mathrm{pFS} 23$, whose LD50 values for guinea-pigs were 10 (2-24) cfu and 267 (67-966) cfu, respectively (fig. 2). Mice infected with strain 231 or its derivatives died in approximately the same periods of time (fig. 3). 


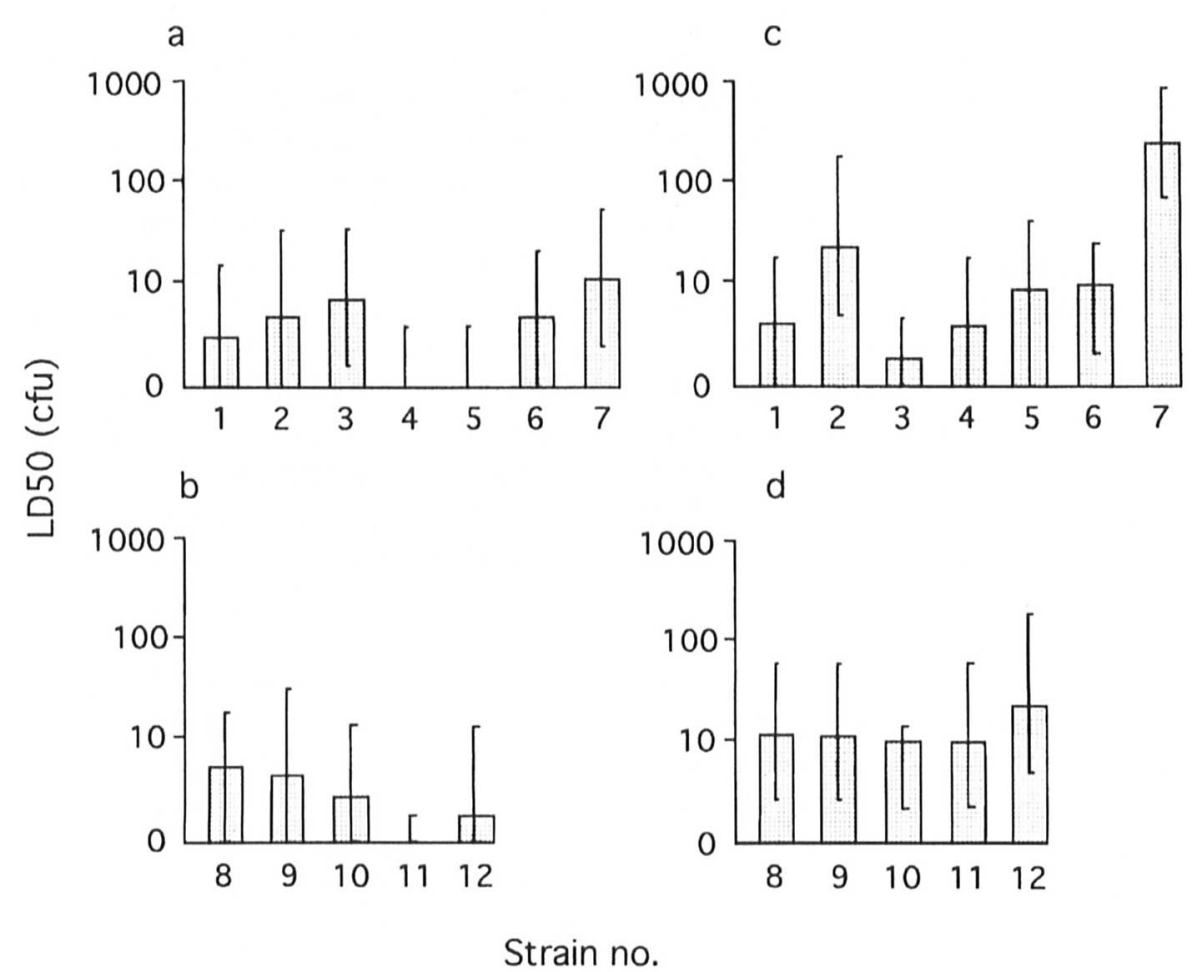

Fig. 2. LD50 of $\mathrm{Fra}^{-}$strains and their parent variants for mice (A, B) and guinea-pigs (C, D). 1, strain no. 231;2, 231pFra $/ \mathrm{pFS} 23 ; 3,231 \mathrm{pFra}{ }^{-}$; 4, 231pPst ${ }^{-} ; 5,231 \mathrm{pPst}^{-} \mathrm{pFra} / \mathrm{pFS} 23 ; 6,231 \mathrm{Psb}^{-} ; 7,231 \mathrm{Psb}^{-} \mathrm{pFra} / \mathrm{pFS} 23 ; 8,358 ; 9,358 \mathrm{pFra} / \mathrm{pFS} 23 ; 10,358 \mathrm{pFra}^{-} ; 11,358 \mathrm{pPst}^{-} ; 12$,

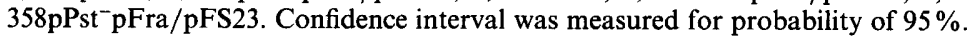
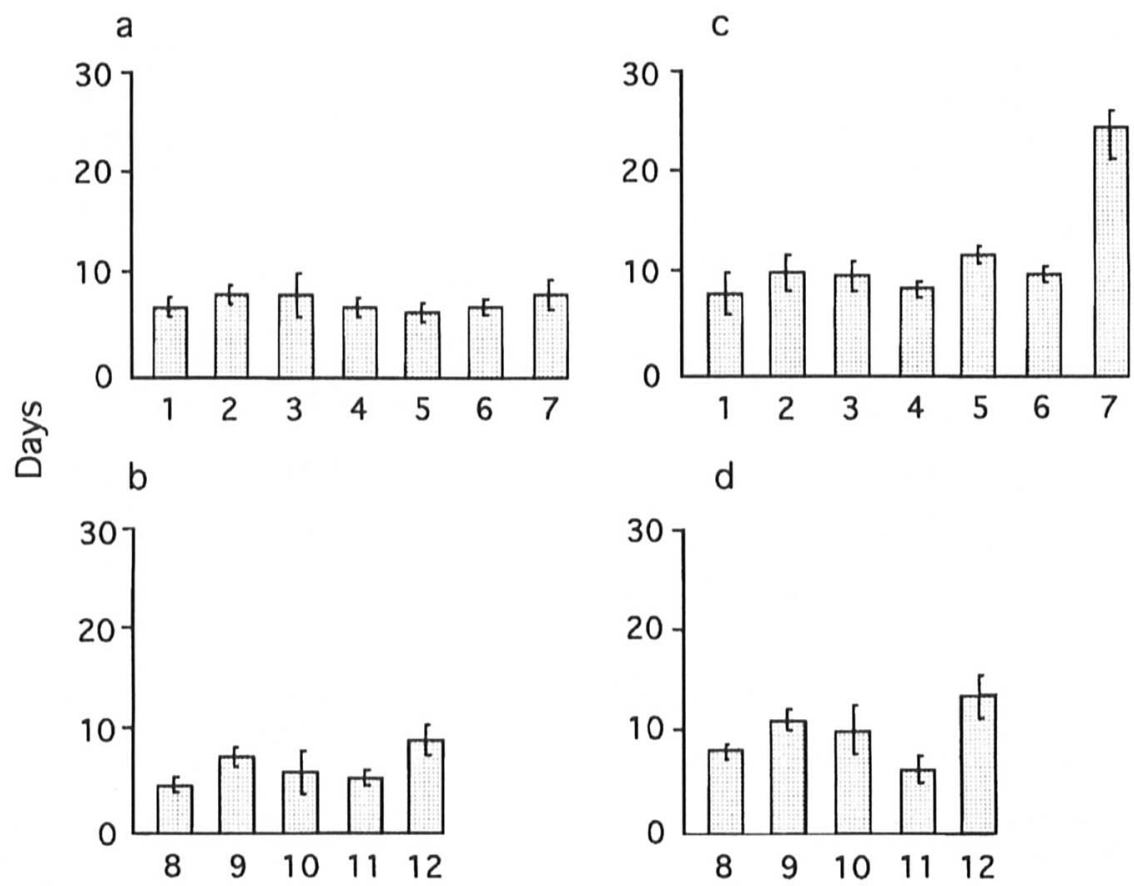

Strain no.

Fig. 3. Average life duration in mice (A,B) and guinea-pigs (C,D) infected with Fra ${ }^{-}$strains and their parent variants. 1, strain no. 231;2, $231 \mathrm{pFra} / \mathrm{pFS} 23 ; 3,231 \mathrm{pFra}^{-} ; 4,231 \mathrm{pPst}^{-} ; 5,231 \mathrm{pPst}^{-} \mathrm{pFra} / \mathrm{pFS} 23 ; 6,231 \mathrm{Psb}^{-} ; 7,231 \mathrm{Psb}^{-} \mathrm{pFra} / \mathrm{pFS} 23 ; 8,358 ; 9,358 \mathrm{pFra} / \mathrm{pFS} 23 ; 10$, $358 \mathrm{pFra}^{-} ; 11,358 \mathrm{pPst}^{-} ; 12,358 \mathrm{pPst}^{-} \mathrm{pFra} / \mathrm{pFS} 23$. Confidence interval was measured for probability of $95 \%$.

However, infection of animals with $\mathrm{Fra}^{-} \mathrm{Tox}^{+}$derivatives of strain 358 caused their death after significantly longer periods. All $\mathrm{Fra}^{-} \mathrm{Tox}^{+}$variants of the strains analysed, except strain $231 \mathrm{pFra} / \mathrm{pFS} 23$, caused the death of guinea-pigs after substantially longer periods of time than their parent strains.

\section{Discussion}

Elucidation of mechanisms that allow pathogenic micro-organisms to resist the immune systems of host species is one of the fundamental medical and biological problems. Resolution of this problem may be 
achieved by identification of the genetic determinants encoding immunogenic proteins, clarification of mechanisms of regulation of their expression, and modelling their antigenic and immunogenic activity in experiments. $Y$. pestis $\mathrm{Fra}^{-}$strains, in comparison with the wild strains, had a selective survival advantage in mice immunised with the live plague vaccine. ${ }^{20}$ Such strains might be produced by insertion of $Y$. pestis insertion elements ${ }^{21.6}$ into the region of the fra operon or by spontaneous elimination of the plasmid $\mathrm{pFra}$. The results of creating $\mathrm{pFra}^{-}$strains under non-selective conditions suggested that such $Y$. pestis variants could be generated in natural plague foci at fairly high frequency and may participate in supporting the epizootic process.

It was reported previously that $Y$. pestis mutations to $\mathrm{Fra}^{-}$phenotype caused a significant reduction of virulence. ${ }^{3.4}$ Present data suggest that this may have been due to the fact that the majority of investigators used $Y$. pestis variants carrying additional unidentified mutations. The present study, with isogenic strain sets, showed that the loss of FI production ability alone or in combination with the absence of murine toxin production did not lead to an increase in LD50 absolute values. Simultaneous loss of these two virulence determinants did not influence the duration of

\section{References}

1. Williams JE, Cavanaugh DC. Chronic infections in laboratory rodents from inoculation of nonencapsulated plague bacilli (Yersinia pestis). Experientia 1983; 39: 408-409.

2. Punski EE, Adamenko NI. Epizootological meaning of Yersinia pestis strains atypical in connection with their different ability of fraction I production. In: Bagirov BG (ed) Medicogeographical problems of arid zone. Ashgabad, Ilim Press. 1982: 36-38.

3. Brubaker RR. The genus Yersinia: biochemistry and genetics of virulence. Curr Top Microbiol Immunol 1972; 57: 111-158.

4. Akimovich VV, Shanina LN. Yersinia pestis variants unable to produce capsular antigen. In: Nikolaev NI (ed) Microbiological and laboratory questions of diagnostics of particularly dangerous infections. Saratov, Privolzhskoe Knizhnoe Press. 1965: 54-58.

5. Zarenkov MI, Goncharova NA. The method of creating Yersinia pestis $\mathrm{Fra}^{-}$mutants. Authors' Certificate No 1439122, USSR, Int. Classif. Index C 12 N 15/00. Byulleten Izobreteniy i Otkrytiy (Moscow) 1988: 43.

6. Portnoy DA, Falkow S. Virulence-associated plasmids from Yersinia enterocolitica and Yersinia pestis. J Bacteriol 1981; 148: 877-883.

7. Tsukano H, Wake A, Sakakibara Y. Plasmid-like properties of the four virulence-associated factors of Yersinia pestis. Microbiol Immunol 1986; 30: 837-848.

8. Cherepanov PA, Mihaylova TG, Karimova GA, Zaharova NM. The fra operon: the complete nucleotide sequence. In: Borovik RV (ed) New technologies and biosystems. Achievements and perspectives. Obolensk, Medbioekonomika Press 1991: 17-20.

9. Galyov EE, Karlishev AV, Chernovskaya TV et al. Expression of the envelope antigen F1 of Yersinia pestis is mediated by the product of caf $1 M$ gene having homology with the chaperone protein PapD of Escherichia coli. FEBS Lett 1991 ; 286: 79-82.

10. Galyov EE, Smirnov OYu, Karlishev AV et al. Nucleotide sequence of the Yersinia pestis gene encoding $\mathrm{Fl}$ antigen and the primary structure of the protein. FEBS Lett 1990; 277: $230-232$.

11. Karlyshev AV, Galyov EE, Abramov VM, Zav'yalov VP. CaflR gene and its role in the regulation of capsule formation of $Y$. pestis. FEBS Lett $1992 ; 305$ : 37-40. survival of the infected animals. However, in the case of absence of FI antigen production alone in the infecting strain, the duration of survival in the infected animals increased. Conversion of plague infection into its chronic form depended on the animal species and the $Y$, pestis parent strain subjected to mutagenesis.

These data allow us to speculate that loss of the ability to produce antigen FI may lead to a decrease of the propagation rate of $Y$.pestis in the host organism. This would be manifest as an increased duration of survival of the infected animals. The loss of both virulence determinants encoded by the plasmid $\mathrm{pFra}$ could lead to a further increase of duration of infection and even to an increase in LD50. However, it is compensated by conversion of energy sources of the bacterial cell from synthesis of the plasmid pFra products to synthesis of other pathogenicity factors and to intensification of cell division. This, respectively, leads to the reduction of duration of survival in the infected animals corresponding to that in animals infected with the wild strains of $Y$. pestis.

These findings are in agreement with the data of Shanina ${ }^{20}$ who described the highly virulent $\mathrm{pFra}^{-}$ strain 358/12.

We thank Tatyana Karavaeva and K. Lobanov for help in preparing the manuscript.

12. Karlyshev AV, Galyov EE, Smirnov OYu, Guzayev AP, Abramov VM, Zav'yalov VP. A new gene of the $f l$ operon of $Y$. pestis involved in the capsule biogenesis. FEBS Lett 1992; 297 : 77-80.

13. Kutyrev VV, Filippov AA, Oparina OS, Protsenko OA. Analysis of Yersinia pestis chromosomal determinants $\mathrm{Pgm}^{+}$and $\mathrm{Pst}^{\mathrm{s}}$ associated with virulence. Microb Pathog 1992; 12: 177-186.

14. Maniatis T, Fritsch EE, Sambrook J. Molecular cloning: A laboratory manual. Moscow, Mir Press. 1984: 89-244.

15. Klassovskiy LN, Stepanov VM, Martinevskiy IL, Shmuter MF, Pak GU. Guidance for studying new Yersinia pestis strains isolated from natural foci. Alma-Ata, Kazakh Agricultural Institute Press. 1972: 1-35.

16. Vieira $J$, Messing J. The pUC plasmids, an M13mp7-derived system for insertion mutagenesis and sequencing with synthetic universal primers. Gene $1982 ; 19$ : 259-268.

17. Anisimov AP, Karlishev AV, Pavlov VM, Kravchenko VI. Construction of recombinant plasmids with stable maintenance in Yersinia pestis recipient cells. In: Anisimov PI (ed) Genetics, microbiololgy and improvement of laboratory diagnostic methods of dangerous diseases. Saratov, SVVKIU Press. 1991: 18-25.

18. Yezhov IN, Yeremin SA, Tuchkov IV, Nikitin AN, Drozdov IG, Anisimov PI. Transformation of Yersinia pestis by electroporation. In: Anisimov PI (ed) Laboratory diagnostics and genetics of virulence of causative agents of dangerous diseases. Saratov, Kommunist Press. 1990: 92-95.

19. Ashmarin IP, Vorob'ov AA. Statistical methods in microbiological research. Leningrad, State Press of Medical Literature. 1962: 85-104.

20. Shanina LN. Immunogenic properties of Pasteurella pestis nonencapsulated strains established in experiments performed on the model of guinea pigs and mice. In: Domaradskiy IV (ed) Genetics, biochemistry and immunochemistry, vol 1. Rostov on Don, Rostov University Press. 1967: 373-381.

21. Filippov AA, Oleinikov PN, Drozdov AV, Protsenko OA. The role of IS-elements of Yersinia pestis in the emergence of calcium-independent mutations. Genetika 1990; 26: $1740-1748$. 